\title{
Service Quality and Customer Satisfaction in the Retailing Industry: Evidence from Sarawak, Malaysia
}

\author{
Leviana Andrew, Nurfazlina Haris, Siti Fatimah Abdul Latiff, Habiel Zakariah
}

\begin{abstract}
These days all organizations are facing challenges in delivering quality services, creating values and satisfying customers, let alone in the retailing industry. The economic instability due to government policy, the rising cost of living, players in the retailing industry are forced to downsize, relocate branch and minimize its operations. Not only that, retailers, specifically hypermarkets which have direct access to individual customers personally try their best to satisfy its customers through monthly promotions, member's discounts, extending physical store to online store and many more. But what are the elements of service quality and how does it affect customer satisfaction? Some studies found that customer's satisfaction seemed to be lower in the retailers that have rigid operating hours. Another study claimed that a long queue was also the culprit for lower customer satisfaction. The truth is, service quality needs assurance, responsiveness, reliability, and tangibility in order to satisfy customers. There was not enough evidence regarding service quality and customers in the retailing industry in Sarawak. Thus, this study seeks to identify the relationship between the two variables in Sarawak's setting. The researchers adapted the SERVQUAL questionnaire to analyze the gap between perceptions and expectations of the customer, concerning the service at a hypermarket. A total of 169 responses from 181 questionnaires distributed were used for the analysis of this study. The results showed that all the variables in the service quality were positively related to customer satisfaction. These findings showed that assurance, responsiveness, reliability, and tangibility are considered as service quality which then translated into the retailers' policy, management, and operations. The study also proved that service quality can be considered as a competitive advantage and should be taken seriously to ensure the survival of the hypermarket.
\end{abstract}

Index Terms: Service quality, SERVQUAL, Customer Satisfaction, hypermarkets.

\section{INTRODUCTION}

Retailing is a cluster of events that is achieved through offering or selling products or services to all types of consumers for their personal, family or institutional use [1]. Therefore, the retailing industry is important for the economies, deeply dynamic and very reactive to economic turnarounds. The service quality within retailing industry is crucial for satisfying and retaining customers and creating loyalty among them. Customer satisfaction can be described

Revised Manuscript Received on April 19, 2019. Technology MARA (UiTM), Kota Samarahan, Malaysia.

Nurfazlina Haris, Business and Management, University of Technology MARA (UiTM), Kota Samarahan, Malaysia.

Siti Fatimah Abdul Latif, Business and Management, University of Technology MARA (UiTM), Kota Samarahan, Malaysia.

Habiel Zakariah, Business and Management, University of Technology MARA (UiTM), Kota Samarahan, Malaysia.
Leviana Andrew, Business and Management, University of

as the result of a comparison of the customers' expectations and their subsequent perceived performance of service quality [2]. A study conducted in South Africa found that South African retail customers have a "shallow commitment" to the store at which they shop due to the poor service quality [3]. Other issues were the rigid and not flexible operating hours [4] and bottlenecks at the payment counter [4]. Therefore, the purpose of this study was to investigate the relationship between tangibility, reliability, responsiveness, assurance and customer satisfaction in the retailing industry. This research used SERVQUAL to analyze the gap between perceptions and expectations of the customers in the retailing industry, in this case, the customers of a hypermarket in Kota Samarahan, Sarawak.

\section{LITERATURE REVIEW}

\section{A. Customer Satisfaction}

Customer satisfaction is a person's feeling of pleasure or disappointment resulting from comparing a products perceived performance or outcome in relation to the person's expectations [5]. Service quality can give good return of investments to the service organization when it is done correctly [5]. The higher the levels of the produced service quality, the higher will be the level of customer satisfaction, which can lead to higher sales and increased intensions [6]. Service quality was defined as an act or a performance that will allow customers to receive benefit [7][8]. Providing excellent service quality to customers in present business environment is very important due to strong market competition. The capability to provide high service quality will strengthen the image, enhance retention of customers, attracting new potential customers via positive word of mouth and eventually increase the profit of the business.

\section{Service Quality}

Service quality has five broad dimensions which are tangibility, reliability, responsiveness, assurance and empathy [9]. However, in this study only four broad dimensions which are tangibility, reliability, responsiveness and assurance were used. Furthermore, the reason the researchers did not choose empathy was because the retailing industry does not necessarily need the experience of understanding another person's condition and it is hard to 
predict what other individual feels or their perspective about the service quality of retailing industry. Tangibility can be defined as an appearance of physical facilities, equipment, personnel and written materials [9]-[10]. Tangibility was the important factor for customer satisfaction [7]-[10]. Other than that, in service organization, customers often rely on tangibility evidence that surrounded the service to form their own evaluation of the services [8]. Reliability is the amount to which the service is brought to the standards expected and promised [11] or it represents the customer getting what they feel they have paid for. Reliability is one of the important factors of customer satisfaction. A study demonstrated that responsiveness was the timely reaction towards the customer's needs [12]. They also suggested that responsiveness has relationship but no significant effect on customer satisfaction [12]-[13]. Assurance is to feel that the services providers are competent to provide the services by degree of trust and confidence of customers. The customer will not be satisfied about the competence of the service provider if he or she does not feel assured [11]. A company should maintain the quality of service provided to its customer. If the service quality received by customer is same or higher that what they perceive, the customer tends to buy the service again. However, if the perceived service is lower than the expected service, the customers will be disappointed and cause them stop their relationship with the concerned company [13].

\section{B. Research Framework}

Figure 1 illustrated the framework that was used in this study.

Service Quality

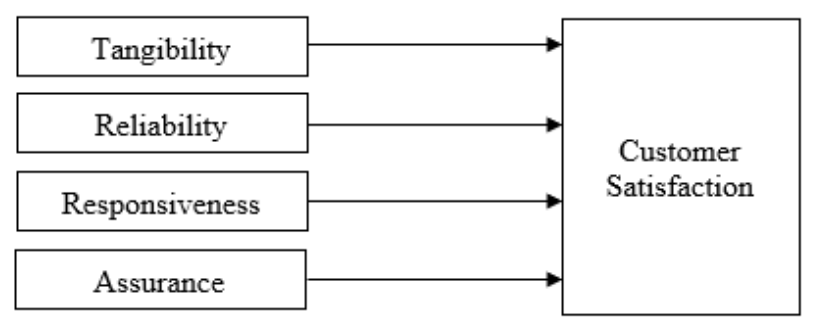

Independent Variables

Dependent Variable

Figure 1. Framework for Service Quality and Customer Satisfaction (Adapted from [9])

In this study, the researchers utilized a correlational methodology. The hypermarket selected has an average 340 customers daily hence the sample size was 181. A nonprobability sampling strategy which is convenience sampling was adopted. The data collection instrument was adapted from SERVQUAL [9] for service quality and customer service [14]. To collect the data, the researchers opened a counter for two consecutive weeks $(9-22$ September) on the entrance and invite any customers who were conveniently available to answer the questionnaire. Prior to the actual data collection, the researchers had requested a formal approval from the management of the hypermarket to conduct the procedure there for two weeks.

\section{METHODOLOGY/MATERIALS}

\section{RESULTS AND FINDINGS}

The researchers personally distributed 181 questionnaires to all customers during the data collection period. A counter was setup at the entrance of the hypermarket. Each customer was personally approached to persuade them to participate in the study. However, there were 12 questionnaires not returned as these respondents brought back the questionnaire and forgot to return to us. Therefore, the findings of this study were based on 169 returned questionnaires (93.4\% return rate).

\section{A. Demographic Profile}

The data shows that out of 169 respondents, most respondents were male $(52.1 \%)$. On the educational background, respondents with bachelor's degree were the majority in this study $(45.6 \%)$ while respondents with Master's Degree were the least population with only 6 . There were 97 respondents said that they shop around 1 to 3 times per month at the hypermarket while only 6 respondents said that they shop more than 6 there. Table 4.1 depicted the demographics information of the respondents.

Table 4.1 Demographic Profile

\begin{tabular}{lll}
\hline \multicolumn{1}{c}{ Profile } & Frequency & Percent \\
\hline $\begin{array}{l}\text { Gender of respondents } \\
\text { Male }\end{array}$ & 88 & 52.1 \\
Female & 81 & 47.9 \\
Educational Background & & \\
SPM & 47 & 27.8 \\
STPM/Diploma & 39 & 23.1 \\
Bachelor Degree & 77 & 45.6 \\
Master's Degree & 6 & 3.6 \\
Frequency of shopping at & & \\
the hypermarket in a month & & \\
1-3 times & 97 & 57.4 \\
$4-6$ times & 56 & 33.1 \\
More than 6 times & 16 & 9.5 \\
\hline
\end{tabular}

\section{B. Descriptive Statistics}

The descriptive statistics were calculated for all the independent and dependent variables. Scores of the descriptive statistics were separated into three ranges such as high scores (3.68 to 5.00), average scores (2.34 to 3.67) and low scores (1 to 2.33). Based on the Table 4.2, the dependent variable which were customer satisfaction was leading the high scores of results with scores of $(M=3.69$, $\mathrm{SD}=.614$ ). This was because majority of the respondents gave the scale from 3-4 for their satisfaction at the hypermarket. This was followed by the independent variable which is Tangibility $(\mathrm{M}=3.49, \mathrm{SD}=.654)$. Most customers moderately agreed with the scale of 3-4 scale given for tangible appearance of physical facilities and equipment of the hypermarket. Next, reliability $(\mathrm{M}=3.41, \mathrm{SD}=.691)$. This was because majority of the respondents gave a scale of 3-4 for reliability as the amount to which the service was brought to the standards expected and promised or it represents customer are getting what they feel they have paid for.

Responsiveness ( $\mathrm{M}=3.48, \mathrm{SD}=.691)$ indicated that most of customers give the scale of 3-4 for responsiveness. 
Finally, assurance is $(\mathrm{M}=3.58, \mathrm{SD}=.557)$ as most of the respondents gave 3-4 scale for assurance because they feel that the services providers were competent in providing the services by degree of trust and confidence of the customers.

Table 4.2 Descriptive Statistics

\begin{tabular}{lll}
\hline Variables & Mean & Std. Deviation \\
\hline Customer satisfaction & 3.6932 & .61438 \\
Tangibility & 3.4985 & .65437 \\
Reliability & 3.4122 & .69128 \\
Responsiveness & 3.4876 & .63087 \\
Assurance & 3.5893 & .55732 \\
\hline
\end{tabular}

\section{Descriptive Statistics}

Table 4.3 reported the reliability test's results for the customer satisfaction and the service quality were acceptable and good. The results showed that Cronbach's Alpha for customer satisfaction is 0.859 , followed by tangibility by 0.791 , Reliability 0.783 , Responsiveness 0.827, and lastly Assurance 0.758.

Table 4.3 Cronbach's Alpha Scores for Variables

\begin{tabular}{lll}
\hline Variables & No. of Items & $\begin{array}{l}\text { Actual Data } \\
(\mathrm{n}=169)\end{array}$ \\
\hline Customer Satisfaction & 7 & 0.859 \\
Tangibility & 4 & 0.791 \\
Reliability & 3 & 0.783 \\
Responsiveness & 5 & 0.827 \\
Assurance & 5 & 0.758 \\
\hline
\end{tabular}

\section{Correlation}

Table 4.4 reported the results of the relationship analysis of correlation coefficient between Service Quality and Customer Satisfaction. It can be summarized that all the variables mostly largely correlated with each other. The findings of data show that the dependent variables of customer satisfaction were correlated with independent variable - service quality. Correlation is significant (0.01) in which $99 \%$ of the respondents were confident to answer.

The Pearson Correlation Coefficient showed that there was a positive, large and significant relationship between tangibility and customer satisfaction $(r=0.524 * *, p<0.05)$. It was found that tangibility can be defined as an appearance of physical facilities, equipment, personnel and written materials [10]. Thus, the appearance of physical facilities and equipment provided at the hypermarket such as air conditioner, bar code scanners and lamps were often looked by the customers for tangibility indications, which were considered as indicators of the service quality [15].

On the other hand, the relationship between reliability and customer satisfaction also was also positive and significant, but moderate $(r=0.353 * *, \mathrm{p}<0.05)$. This was due to the services of the hypermarket are brought to the standards expected and promised or it represents the customers getting what they feel they have paid for [11]-[16]. For instance, the respondents perceived that the hypermarket fulfilled the promised terms and conditions which will not go against their customer's interests [17].

The relationship between responsiveness and customer satisfaction was positive, large and significant ( $r=0.519 * *$, $\mathrm{p}<0.05)$. This moderate relationship reflected that the employees of the hypermarket are always prompt to customers' complaints and enquiries. For instance, a customer service counter is been set up near the entrance to handle item storage, reward redemptions and membership card matters. This finding was consistent with several studies that showed customers' perception of service quality is improved when organization improved its response time [14]-[18].

Finally, the relationship between assurance and customer satisfaction was also positive, large and significant $\left(r=0.545^{* *}, \mathrm{p}<0.05\right)$. The respondents perceived the hypermarket was competent to provide services through its employees' work ethics and attitude. This also been observed in the hypermarket's assurance to provide certified-Halal product to the customers. The findings were consistent with a study which found that employees' capabilities, abilities and trustworthiness contribute to customer satisfaction $[19,20]$.

It can be concluded that tangibility, reliability, responsiveness and assurance are all factors of service quality and contribute to customer satisfaction.

Table 4.7 Relationship between Service Quality and Customer Satisfaction $(n=169)$

\begin{tabular}{lccccc}
\hline \multicolumn{1}{c}{ Variables } & 1 & 2 & 3 & 4 & 5 \\
\hline 1. Customer Satisfaction & 1 & $0.524^{* *}$ & $0.353^{* *}$ & $0.519^{* *}$ & $0.545^{*}$ \\
2. Tangibility & & 1 & $0.634^{* *}$ & $0.615^{* *}$ & $0.463^{*}$ \\
3. Reliability & & & 1 & $0.648^{* *}$ & $0.536^{*}$ \\
4. Responsiveness & & & & 1 & $0.649^{*}$ \\
5. Assurance & & & & & 1
\end{tabular}

**. Correlation is significant at the 0.01 level [2-tailed].

\section{CONCLUSION}

It can be determined that the respondents at the hypermarket agreed that the service quality influenced their satisfaction and experiences. The service quality of a hypermarket was influenced by tangibility, reliability, responsiveness and assurance. Hence, the managers should put in more efforts in these aspects. This may include developing strategies to improve the quality of service delivery as well as training for all employees.

The layouts of each products can be managed in a more organized way, for example, put related items in the same row or section or so that customers can find the products easily. As for future researchers, it is recommended that more studies should be conducted in the retailing industry as there were limited to be referred and it would be interesting to see a comparison of service quality at different hypermarkets in order to explain more on the relationship between service quality and customer satisfactions.

\section{ACKNOWLEDGMENT}

The researchers would like to thank Marta Nuti James, a student of Bachelor of Office Systems Management (Hons.) 
from the University of Technology MARA (UiTM) Sarawak Branch for her assistance in this study.

\section{REFERENCES}

1. J. Castillo. (2017). The Relationship between Big Five Personality Traits, Customer Empowerment and Customer Satisfaction in the Retail Industry. Journal for Business and Retail Management Research, 11(2).

2. C. Herrington, and S. Weaven. (2009). E-retailing by banks: e-service quality and its importance to customer satisfaction. European Journal of Marketing. 43(9/11), pp. 1220-31.

3. J. Beneke. (2010). Consumer perceptions of private label brands within the retail grocery sector of South Africa. African Journal of Business Management. 4(2), pp. 20320.

4. M. Jayaraman, C. Shankar, C. and W. M. Hor. (2010) Service quality delivery and its impact on customer satisfaction in the banking sector in Malaysia. International Journal of Innovation, Management and Technology. 1(4), pp. 168-74.

5. C. Silvestri, B. Aquilani, and A. Ruggieri. (2017) Service quality and customer satisfaction in thermal tourism. The TQM Journal. 29(1), pp. 55-81.

6. A. Prakash, R. P. Mohanty, and S. P. Kallurkar. (2011). Service quality modelling for life insurance business using neural networks. International Journal of Productivity and Quality Management. 7(3), pp. 263-86.

7. H. Zaim, N. Bayyurt, S. Zaim. (2010). Service Quality And Determinants Of Customer Satisfaction In Hospitals: Turkish Experience. International Business \& Economics Research Journal. 9(5), pp. 51-8.

8. A. Parasuraman, V. A. Zeithaml, and L. L. Berry. (1985). More on improving service quality measurement. Journal of Retailing. 140.

9. A. Parasuraman, V. A. Zeithaml, and L. L. Berry (1985). A Conceptual Model of Service Quality and Its Implications for Future Research. Journal of Marketing. 59(4), pp. 41-50.

10. V. A. Zeithaml, A. Parasuraman, and L. L. Berry. (1990). Delivering Quality Service: Balancing Customer Perceptions and Expectations. 226.

11. K. O. Siddiqi. (2011). Interrelations between Service Quality Attributes, Customer Satisfaction and Customer Loyalty in the Retail Banking Sector in Bangladesh. International Journal of Business and Management. 6(3), pp. 12-36.

12. J. Munusamy, S. Chelliah, and H. W. Mun. (2010). Service quality delivery and its impact on customer satisfaction in the banking sector in Malaysia. International Journal of Innovation, Management and Technology. 1(4), pp. 168-74.

13. A. A. S. Mohammad, and S. Y. M. Alhamadani. (2011). Service Quality Perspectives and Customer Satisfaction in Commercial Banks Working in Jordan. Middle Eastern Finance and Economics. 14, pp. 60-72.

14. C. Lu, C. Berchoux, M. W. Marek, and B. Chen. (2015). Service quality and customer satisfaction: qualitative research implications for luxury hotels. International Journal of Culture, Tourism and Hospitality Research. 9(2), pp. 168-82.

15. V. Kaura, C. S. D. Prasad, and S. Sharma. (2015). Service quality, service convenience, price and fairness, customer loyalty, and the mediating role of customer satisfaction. International Journal of Bank Marketing. 33(4), pp. 404-22.

16. J. M. Kabir. (2016). Factors Influencing Customer Satisfaction at a Fast Food Hamburger Chain: The Relationship Between Customer Satisfaction and Customer Loyalty. Proquest Dissertation: Wilmington.
17. S. Moghavvemi, S. T. Lee, S. P. Lee. (2018). Perceived overall service quality and customer satisfaction: A comparative analysis between local and foreign banks in Malaysia. International Journal of Bank Marketing. 36(5), pp. 908-30.

18. H-Y. Lin. (2010). The Study of Exercise Participation Motivation and the Relationship Among Service Quality, Customer Satisfaction, and Customer Loyalty at Selected Fitness Health Clubs in Taipei City, Taiwan. Alabama: United States Sports Academy; 2010.

19. S. Sumaedi, G. Y. B. Mahatma, and N. Metasari. (2012). An empirical study of state university students' perceived service quality. Quality Assurance in Education. 20(2), pp. 164-83.

20. C. Fornell, M. D. Johnson, E. W. Anderson, J. Cha, and B. E. Bryant. (1996). The American Customer Satisfaction Index: Nature, Purpose, and Findings. Journal of Marketing. 60(4):7-18.

\section{AUTHORS PROFILE}

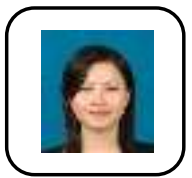

Leviana Andrew hold a Master's Degree in Office Systems Management from University of Technology MARA (UiTM) Malaysia. She works in the same university as a faculty member and has several years working experience in the areas of teaching and research. Her research interests include service quality, leadership, quality of work life and emotional intelligence. She has few design and innovation copyrights on mobile application related to quality of life improvement.

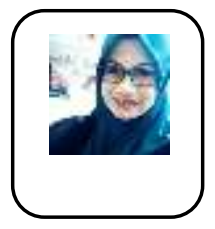

Nurfazlina Haris completed her degree of M.Sc in Information Technology from Universiti of Technology MARA (UiTM) Malaysia in 2013. She is a faculty member of Business Management, Universiti Technology MARA (UiTM) Sarawak Branch. She has several publications to her credit in reputable journals. She is also a member of Mendeley in advisor program and adapted to a Netnography research.

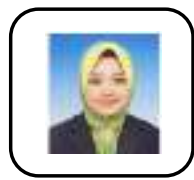

Siti Fatimah Abdul Latif obtained her Master's Degree in Office Systems Management from University of Technology MARA (UiTM) Malaysia. Her current tenure is with University Technology MARA (UiTM Sarawak Branch. She has published several researche primarily in the area of employee motivation and employee job satisfaction. She is interested in service quality, emotional intelligence among educators and ergonomics studies.

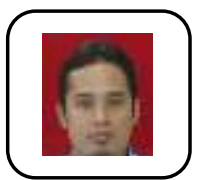

Habiel Zakariah is a lecturer at the University Technology MARA [UiTM] Sarawak Branch [M.Sc. Information Technology]. $\mathrm{He}$ is interested in $\mathrm{e}$ commerce studies, systems development and life cycle and knowledge sharing. He received Gold Award in the 1000 Pitching National Competition in 2016. His current research focuses on personality traits as factors contributing to job performance among academician. 